\title{
The analysis of densitometric and geometric parameters of bilateral proximal phalanges in horses with the use of peripheral quantitative computed tompgraphy
}

\author{
Małgorzata Dzierzęcka ${ }^{1 *}$ and Anna Charuta²
}

\begin{abstract}
Background: Proximal phalanges in horses are among bones that are most prone to injuries. So far, the detailed analysis of densitometric and geometric parameters of both front legs proximal phalanges in horses has not been investigated. The aim of this study was to compare the densitometric and geometric parameters between proximal phalanges in equine both front legs with the use of peripheral quantitative computed tomography (pQCT).

Methods: The study material comprised isolated both front legs proximal phalanges derived from 22 horses. The structure analysis of the proximal phalanges was conducted with the pQCT. The following bone parameters were determined: bone mineral content, volumetric bone mineral density, total bone area, trabecular area, cortical area, cortical thickness, periosteal circumference, endocortical circumference, Strength Strain Index. Tomographic analysis of proximal phalanges was conducted at three levels: at 15\%, 50\% and $85 \%$ of the bone length.

Results: The statistical analysis showed that both the densitometric and geometric parameters of the bone at 50\% and $85 \%$ of its length, did not present any statistically significant differences for the left or right proximal phalanges of the forelimb. At the same time, all examined parameters measured at 15\% of the bone length, in the vicinity of the proximal metaphysis revealed significant statistical differences between both front legs proximal phalanges.

Conclusions: The proximal phalanx parameters in the forelimbs are significantly different for the left and right proximal phalanx at 15\% of the length and they indicate higher Strength Strain Index of the left bone in this location. The densitometric and geometric parameters of the bone at $50 \%$ and $85 \%$ of its length, did not present any statistically significant differences for the left or right proximal phalanges of the left and right forelimbs. The most serious changes caused by asymmetrical load of the thoracic limbs in horses occur near the proximal metaphysis, where the spongious substance is most abundant. This may happen because the metabolism of the spongious bone tissue is eight times faster compared to the compact bone tissue. Thus, any changes, including those caused by asymmetrical strain exerted on the right and left thoracic limbs, are the earliest to be observed.
\end{abstract}

Keywords: Horse, Proximal phalanx, Bone parameters, Computed tomography

\footnotetext{
* Correspondence: malgorzatadzierzecka@wp.pl

'Department of Morphological Science, Faculty of Veterinary Medicine,

Warsaw University of Life Sciences, Nowoursynowska 166, Warsaw 02-776,

Poland

Full list of author information is available at the end of the article
} 


\section{Background}

Proximal phalanx fractures are one of the most common injuries that occur in the equine forelimb [1-4]. Based on four-year observations of 850 two-year old Thoroughbreds that underwent training, changes were found in as many as 19 out of 47 of all the limb bone fractures. Pastern bone fractures comprised $39.6 \%$ of all the fractures that were recorded in the 4-year-long observation period. Fractures of proximal navicular bone were slightly less frequent - 11 cases (22.9\%) Fractures of other bones were rare [1]. Proximal phalanges are most often subject to longitudinal fractures. Such fractures are probably facilitated by the characteristic shape of the proximal bone end. On the articular surface of their proximal end, there is an the sagittal groove of the proximal phalanx with the sagittal ridge of the third metacarpal bone. The sagittal ridge acts as a wedge by "squeezing into" the cup-shaped depression, which can facilitate this type of fractures. It is also suggested that the decrease in the bone tissue parameters in the vicinity of proximal metaphysic of the proximal phalanx can be conducive to this type of fractures. Bone fractures are more likely to occur in the context of low bone tissue parameters such as decrease in the number of bone trabeculae, their volume, density and width $[2,3]$. Unfortunately, there are few reports on the bone tissue parameters of the proximal phalanges. The analysis comprises only densitometric parameters of the proximal phalanges [5]. However, the mechanic strength of the bone tissue, which affects its supporting functions, is affected not only by the mineral composition but also its spatial architecture [6-8]. Unfortunately, the evaluation of bone tissue quality is most often based on densitometric methods. The reason for the imperfections of these methods is the inability to evaluate the spatial structure of the bone trabeculae. The mineralization level is not the only factor affecting bone durability as the bone trabeculae architecture is also very important $[8,9]$. Computed Tomography (CT) allows for studying the geometry of the examined bone, providing important information regarding the bone microarchitecture [10].

The asymmetry of long bones has been examined in humans. The studies on this subject explicitly showed that there is a statistically significant difference between the bilateral thoracic limbs in humans. It was proved that the densitometric parameters in the studied bones are tightly related to hand preference [11-13]. Importantly, it was also shown that densitometric parameters of the bilateral femoral bones in humans are linked to handedness [14].

Particular feature of highly developed animals is the fact that they do not move in straight position, but tend to twist their body into one side. It can be said that they have a left-side or right-side tendency $[15,16]$. The right- sided have a natural tendency to move left, therefore in the open space most people and animals come full circles left. Right-sidedness is observed only in highlydeveloped mammals, including horses [17]. It is manifested while starting galloping with so called left leg more willingly, while the left thoracic limb is the leading one, so it is put forward first during horse's action while running. A right-sided horse has a natural tendency to 'break' left, which means that when a horse gets scared of something, it usually nips out left. It was also observed that facing an obstacle, horses more frequently break left in front of it [17].

The fact the unequal loading inspired a lot of scientists and doctors to examine the influence of the unequal loading, not only on shaping but also on exposure to injuries of particular structures of the locomotor's system of the bilateral limbs.

Comparison of the bilateral long bones of limbs in horses was conducted by morphometric methods. The studies confirmed the phenomenon of asymmetry regarding the femoral bones in this species [18] and the equine third metacarpal [19]. Importantly recent study found that the majority of proximal phalanx fractures in horses occur in the right leg [20].

In contrast to human medicine, where the $\mathrm{pQCT}$ method is becoming more frequently used [21-23] it is rarely applied in horses. It is related with species specificity, e.g. difficulty with keeping the animal still for several minutes, dimensions etc. [24].

Unfortunately, even tests on isolated equine bones with the use of the pQCT method are performed very rarely. So far, the above method has been used on radius and tibia [24,25], third metacarpal bone [26] and the distal sesamoid bone [27]. According to the authors' knowledge, there is still insufficient number of research studies on comparative analysis of both densitometric and geometric parameters of the both front legs proximal phalanges in horses with the use of pQCT.

There is still lack of writing touching upon the issue of influence of the increased loading of one side of horse body on shaping of microstructure of long bones in bilateral limbs. The umber of studies that thoroughly compare densitometric and geometric parameters between bilateral ones of limbs in this species are still insufficient.

Due to the lack of studies that focus on how increased one-side load affects the microstructure of long bones in bilateral limbs and their densitometric features, studies that do address the issue are very important because of their cognitive value. Moreover, research on the possible influence of asymmetrical load on the pastern bone parameters may provide information on the nature of remodeling in the pastern bone tissue as a result of load.

The aim of this study was to compare the densitometric and geometric parameters between the both front 
legs proximal phalanges in the equine forelimb at $15 \%$, $50 \%$ and $85 \%$ of bone length with the use of pQCT. It was also analyzed whether the right or left bone preference affected the values of the above parameters at the three measurement levels.

\section{Methods}

\section{Horses}

The material consisted of 44 proximal phalages from the front legs of 22 horses aged 2.5-15 (Table 1). There were no animals in which any anomalies concerning the pastern bones had been stated intravitally, and their slaughtering or death were not the result of any diseases. Before slaughter, or during visual inspection in the case of dead animals, morphological description was prepared based on the constitutional type of the horses. Each horse, according to its physical constitution, represented one of the following types: Warmblood horses (dolichomorphic type or light) and Coldblood horses (brachymorphic type or heavy) [28]. Warmblood horses were represented by Polish Halfbred Horse (warmblood breed crossed with thoroughbreds and used for sports purposes) (body weight of the adult horses ranged from 450 to $550 \mathrm{~kg}) \mathrm{n}=9$. Coldblood horses on the other hand, comprised the animals from private farms in the Mazovia region - Polish Coldblood Horses, which are mainly used as draft animals (body weight of the adult horses ranged from 600 to $750 \mathrm{~kg}$ ), $\mathrm{n}=13$.

Following the visual inspection, autopodia in thoracic limbs were dissected and in order to isolate the pastern bones from the soft tissues. After isolating, the bones were marked, placed in air-tight plastic bags and then kept 4 months in the temperature of $-20^{\circ} \mathrm{C}$.

\section{Computed tomography}

The use of high resolution pQCT XCT Research SA Plus (Stratec Medizintechnik GmbH, Pforzheim Germany) allowed for analyzing the densitometric and geometric parameters of the proximal phalanges in horses. The following densitometric parameters were determined: BMC bone mineral content per $1 \mathrm{~mm}$ slice in $\mathrm{mg} / \mathrm{mm}$ and vBMD - volumetric bone mineral density in $\mathrm{mg} / \mathrm{cm}^{3}$, the mean density of the total bone and geometrical parameters:

TOT_A - total bone area in $\mathrm{mm}^{2 ;}$ cross sectional area of the bone, after the soft tissue has been peeled off,

Table 1 Age, sex, morphological type, use and reason for euthanasia in 22 used for Xtreme CT of the proximal phalanx

\begin{tabular}{|c|c|c|c|c|c|}
\hline Case number & Age in years & Sex & $\begin{array}{l}\text { Morphological type: Polish Coldblood } \\
\text { Horse (coldblood-heavy)-H; Polish } \\
\text { Halfbred Horse (warmblood-light)-L }\end{array}$ & Use & $\begin{array}{c}\text { Reason for } \\
\text { euthanasia or } \\
\text { slaughtering house }\end{array}$ \\
\hline 1. & 7 & stallion & $\mathrm{L}$ & jumper & Bone fracture \\
\hline 2. & 7 & gelding & L & pleasure & Ruptured tendon \\
\hline 3. & 4 & gelding & $\mathrm{H}$ & farm & Slaughtering house \\
\hline 4. & 15 & gelding & $\mathrm{H}$ & farm & Slaughtering house \\
\hline 5. & 6 & mare & $\mathrm{H}$ & farm & Heart disease \\
\hline 6. & 4 & mare & $\mathrm{L}$ & jumper & Ruptured tendon \\
\hline 7. & 7 & gelding & $\mathrm{L}$ & pleasure & Kidney disease \\
\hline 8. & 15 & mare & $\mathrm{H}$ & farm & Metritis \\
\hline 9. & 4 & gelding & $\mathrm{H}$ & farm & Colic \\
\hline 10. & 7 & mare & $\mathrm{L}$ & pleasure & Colic \\
\hline 11. & 4 & mare & $\mathrm{L}$ & pleasure & Ruptured tendon \\
\hline 12. & 4 & mare & $\mathrm{L}$ & pleasure & Bone fracture \\
\hline 13. & 12 & gelding & $\mathrm{H}$ & farm & Slaughtering house \\
\hline 14. & 2,5 & stallion & $\mathrm{L}$ & pleasure & Ruptured tendon \\
\hline 15. & 7 & mare & $\mathrm{H}$ & farm & Slaughtering house \\
\hline 16. & 8 & gelding & $\mathrm{H}$ & farm & Slaughtering house \\
\hline 17. & 8 & mare & L & pleasure & Metritis \\
\hline 18. & 5 & mare & $\mathrm{H}$ & farm & Colic \\
\hline 19. & 7 & mare & $\mathrm{H}$ & farm & Slaughtering house \\
\hline 20. & 4 & stallion & $\mathrm{H}$ & farm & Ruptured tendon \\
\hline 21. & 5 & gelding & $\mathrm{H}$ & farm & Slaughtering house \\
\hline 22. & 5 & gelding & $\mathrm{H}$ & farm & Slaughtering house \\
\hline
\end{tabular}


TRAB_A - trabecular area in $\mathrm{mm}^{2}$; cross sectional area of the trabecular area after the cortical and subcortical area has been peeled off,

CRT_A cortical area in $\mathrm{mm}^{2}$, the area that is assigned to be pure cortical, CRT_THK_C - the mean cortical thickness in $\mathrm{mm}$,

PERI C - periosteal circumference in $\mathrm{mm}$,

ENDO_C - endocortical circumference in $\mathrm{mm}$,

SSI = RP_CM_W - Strength Strain Index - moment of resistance in $\mathrm{mm}^{3}$.

Tomographic analysis was performed at 15\%, 50\% and $85 \%$ of the bone length. The study was performed at the voxel size of $0.07 \mathrm{~mm}^{3}$ and scanning speed of $4 \mathrm{~mm} /$ min. The analyzed areas were determined by initial scanning $(20 \mathrm{~mm} / \mathrm{s})$ and after morphometric measurements of the proximal phalanges. The threshold coefficient, which differentiates the compact bone from the cancellous bone was set at $0.900 \mathrm{~cm}^{-1}$. The thickness of the analysed slices was $0,07 \mathrm{~mm}$;

Measurement areas of every bone were determined with the use of digital slide caliper of the length of every analysed bone. Next, the obtained results were entered in the computed tomography scanner software. After preliminary scanning, it was possible to set the reference line, tangent to the joint surface. Since the bone length had already been entered, now only the measurement lines in the selected bone area had to be added. In our study, those were the lines at $15 \%, 50 \%$ and $85 \%$ of the bone length.

\section{Statistical analysis}

The analysis was performed separately for the previously described three measurement levels for two groups of proximal phalanges - left and right. The first step of the statistical analysis was to verify the compliance with the normal distribution. For the features, which were not compliant with the normal distribution, the differences between the left and right proximal phalanges were tested with a non-parametric test - Wilcoxon paired samples $(Z) p \leq 0.05$. For the remaining features, whose distribution was compliant with normal distribution, the differences between the bilateral bones were tested with the $\mathrm{t}$-Student test $(\mathrm{t})$ for combined variables at $\mathrm{p} \leq 0.05$.

The densitometric and geometric features in the bilateral proximal phalanges (left and right in thoracic limb) in horses at $50 \%$ of the bone length and at $15 \%$ and $85 \%$ of the bone length were described and compared. The differences between parameters for the both front legs proximal phalanges, depending on the measurement location, were presented in tables and on box plots. The whiskers in boxes indicate the minimal and maximal values of a given feature. The box size shows the variability in $50 \%$ of the specimen (threshold of $25-75 \%$ ).
Additionally, the graph shows the average value. All calculations were performed using the Statistica 9.0 software (StatSoft, Inc. Tulsa, USA), at $\mathrm{p} \leq 0.05$.

\section{Results}

The densitometric and geometric parameters of the both front legs proximal phalanges in horses were determined by pQCT at $15 \%, 50 \%$ and $85 \%$ of the bone length. The results comparing the parameters of the bilateral proximal phalanges on three examined sections are illustrated in Table 2. The statistical analysis showed that both the densitometric and geometric parameters of the bone at $50 \%$ and $85 \%$ of its length, did not present any statistically significant differences for the left or right proximal phalanges of forelimbs. It is confirmed by the values of $t$-Student test $(\mathrm{t})$ and the Wilcoxon paired samples $(Z)$ presented in Table 2 . The $\mathrm{t}$-Student values for the dependent samples prove that there is no difference between the left and right forelimbs at 50\% of the bone shaft as far as the investigated features are concerned. The values of probability are $>0.05$. The probability values indicate that the null hypotheses assuming lack of differences between the left and the right limbs were taken as acceptable at the probability of $95 \%$.

\begin{tabular}{|c|c|c|c|}
\hline \multicolumn{4}{|c|}{ The value of tests } \\
\hline Bone parameter & 15\% slice & $50 \%$ slice & $85 \%$ slice \\
\hline \multirow[t]{2}{*}{$\mathrm{BMC} \mathrm{mg} / \mathrm{mm}$} & $Z=3.977^{* *}$ & $Z=0.081$ & $t=0.348$ \\
\hline & $p=0.000$ & $p=0.935$ & $p=0.730$ \\
\hline \multirow[t]{2}{*}{$\mathrm{vBMD} \mathrm{mg} / \mathrm{cm}^{3}$} & $Z=3.782^{* *}$ & $Z=0.828$ & $Z=0.666$ \\
\hline & $p=0.000$ & $p=0,407$ & $p=0.505$ \\
\hline \multirow[t]{2}{*}{ TOT_A mm² } & $Z=4.12^{* *}$ & $t=-0.527$ & $t=-0,735$ \\
\hline & $p=0.000$ & $p=0,603$ & $p=0.470$ \\
\hline \multirow[t]{2}{*}{ TRAB_A mm ${ }^{2}$} & $Z=4.107^{* *}$ & $t=-0.55$ & $\mathrm{t}=-0.723$ \\
\hline & $p=0.000$ & $p=0,588$ & $p=0.477$ \\
\hline \multirow[t]{2}{*}{ CRT_A mm² } & $t=-2.165^{*}$ & $t=1.246$ & $Z=0.016$ \\
\hline & $p=0.002$ & $p=0,226$ & $p=0,987$ \\
\hline \multirow[t]{2}{*}{ CRT_THK_C mm } & $\mathrm{t}=4.42^{* *}$ & $Z=1.315$ & $t=0.999$ \\
\hline & $p=0.000$ & $p=0,188$ & $p=0,328$ \\
\hline \multirow[t]{2}{*}{ PERI C mm } & $Z=4.12^{* *}$ & $t=-0.416$ & $Z=0.146$ \\
\hline & $p=0.000$ & $p=0,681$ & $p=0,883$ \\
\hline \multirow[t]{2}{*}{ ENDO_C mm } & $t=-12.468^{* *}$ & $t=-1.013$ & $t=-0.948$ \\
\hline & $p=0.000$ & $p=0,332$ & $p=0,354$ \\
\hline \multirow[t]{2}{*}{ RP_CM_W mm ${ }^{3}$} & $Z=3.945^{* *}$ & $Z=0.535$ & $t=0.00$ \\
\hline & $p=0.000$ & $p=0,592$ & $p=1,000$ \\
\hline
\end{tabular}

*significant statistical differences at $\mathrm{P} \leq 0.05$.

** highly significant statistical differences at $\mathrm{P} \leq 0.01$. 
Table 3 Descriptive statistics for 22 pairs of pastern bones examined at $15 \%$ of the bone shaft

\begin{tabular}{|c|c|c|c|c|c|c|c|c|}
\hline \multirow{2}{*}{$\begin{array}{l}\text { Bone } \\
\text { parameter }\end{array}$} & \multicolumn{4}{|c|}{ Right proximal phalanx } & \multicolumn{4}{|c|}{ Left proximal phalanx } \\
\hline & Minimum & Maximum & Mean & SD & Minimum & Maximum & Mean & SD \\
\hline $\mathrm{BMC} \mathrm{mg} / \mathrm{mm}$ & 488 & 932 & 764 & 105 & 635 & 1305 & 1041 & 182 \\
\hline $\mathrm{vBMD} \mathrm{mg} / \mathrm{cm}^{3}$ & 538 & 820 & 713 & 90 & 454 & 669 & 554 & 60 \\
\hline CRT_THK_C mm & 4 & 8 & 6 & 1 & 4 & 7 & 5 & 1 \\
\hline RP_CM_W mm $\mathrm{m}^{3}$ & 4145 & 10027 & 7630 & 1658 & 4784 & 21246 & 13160 & 4518 \\
\hline TOT_A mm² & 816 & 1371 & 1080 & 153 & 1113 & 2496 & 1894 & 351 \\
\hline TRAB_A mm² & 367 & 617 & 486 & 69 & 501 & 1121 & 852 & 158 \\
\hline CRT_A mm² & 404 & 737 & 609 & 85 & 408 & 903 & 681 & 148 \\
\hline PERI C mm & 101 & 131 & 116 & 8 & 118 & 177 & 154 & 15 \\
\hline ENDO_C mm & 58 & 99 & 76 & 11 & 94 & 149 & 123 & 15 \\
\hline
\end{tabular}

Detailed values for the described densitometric and geometric parameters of the both front legs proximal phalanges in horses examined at $15 \%, 50 \%$ and $85 \%$ of the bone length were presented in Tables $3,4,5$.

All bone parameters measured at $15 \%$ of the bone length proved to be statistically significantly different between the left and right proximal phalanges (Table 5). Both the densitometric parameters measured at $15 \%$ of the bone length proved to be significantly different between the left and right proximal phalanges. And so the bone mineral content was significantly higher in the left bone than in the right bone. Volumetric bone mineral density in this level was significantly higher in the right bone. Both the bone geometric parameters, describing bone surface in the analysed area, recorded in 15\% of the bone length, were also significantly different for bilateral proximal phalanges. Average analysed total bone area was larger for the left proximal phalanges. Trabecular area analysed was also significantly larger in the left proximal phalanx, compared the right proximal phalanx. Differences between geometric parameters for the compact bone tissue in $15 \%$ of the bone length were also statistically significant for the both front legs proximal phalanges. Cortical thickness was larger in right bone but cortical area was larger in the left one. This was due to the fact that left proximal phalanges displayed significantly higher periosteal circumference and endocortical circumference, and so significantly larger diameter, which resulted in a larger cortical area, even though cortical thickness was smaller. Periosteal circumference and endocortical circumference of the left side bones was significantly higher. Expected Strength Strain Index - SSI was significantly higher in the left proximal phalanx than in the right one. Due to the fact that all bone parameters measured at $15 \%$ of the bone length proved to be statistically significantly different in the left and right proximal phalanges (Table 2), they were described in detail and illustrated in Figures 1, 2, 3, 4, 5.

\section{Discussion}

Comparative analyses of bilateral limb bones, conducted with the use of the pQCT method, have been performed on the radius and tibia at $50 \%$ and $80 \%$ of the bone length. The conducted research did not show statistically

Table 4 Descriptive statistics for 22 pairs of pastern bones examined in the middle of the bone shaft (50\% of the bone length)

\begin{tabular}{|c|c|c|c|c|c|c|c|c|}
\hline \multirow{2}{*}{$\begin{array}{l}\text { Bone } \\
\text { parameter }\end{array}$} & \multicolumn{4}{|c|}{ Right proximal phalanx } & \multicolumn{4}{|c|}{ Left proximal phalanx } \\
\hline & Minimum & Maximum & Mean & SD & Minimum & Maximum & Mean & SD \\
\hline $\mathrm{BMC} \mathrm{mg} / \mathrm{mm}$ & 482 & 874 & 744 & 99 & 470 & 857 & 730 & 111 \\
\hline vBMD $\mathrm{mg} / \mathrm{cm}^{3}$ & 560 & 823 & 741 & 68 & 538 & 820 & 722 & 84 \\
\hline CRT_THK_C mm & 5 & 8 & 7 & 1 & 4 & 8 & 6 & 1 \\
\hline RP_CM_W mm $\mathrm{m}^{3}$ & 2999 & 10218 & 7132 & 1783 & 2937 & 10027 & 7053 & 1929 \\
\hline TOT_A mm² & 585 & 1255 & 1013 & 163 & 592 & 1372 & 1024 & 195 \\
\hline TRAB_A mm² & 263 & 565 & 455 & 73 & 266 & 617 & 461 & 88 \\
\hline CRT_A mm $\mathrm{mm}^{2}$ & 427 & 707 & 601 & 78 & 397 & 695 & 585 & 83 \\
\hline PERI C mm & 86 & 126 & 112 & 9 & 86 & 131 & 113 & 11 \\
\hline ENDO_C mm & 45 & 96 & 71 & 11 & 50 & 99 & 73 & 13 \\
\hline
\end{tabular}


Table 5 Descriptive statistics for 22 pairs of pastern bones examined at $85 \%$ of the bone shaft

\begin{tabular}{|c|c|c|c|c|c|c|c|c|}
\hline \multirow{2}{*}{$\begin{array}{l}\text { Bone } \\
\text { parameter }\end{array}$} & \multicolumn{4}{|c|}{ Right proximal phalanx } & \multicolumn{4}{|c|}{ Left proximal phalanx } \\
\hline & Minimum & Maximum & Mean & SD & Minimum & Maximum & Mean & SD \\
\hline $\mathrm{BMC} \mathrm{mg} / \mathrm{mm}$ & 550 & 991 & 819 & 113 & 544 & 980 & 813 & 119 \\
\hline $\mathrm{VBMD} \mathrm{mg} / \mathrm{cm}^{3}$ & 530 & 776 & 679 & 62 & 430 & 760 & 661 & 83 \\
\hline CRT_THK_C mm & 4 & 7 & 6 & 1 & 2 & 7 & 6 & 1 \\
\hline RP_CM_W mm ${ }^{3}$ & 4225 & 12123 & 9032 & 2256 & 2775 & 12615 & 8883 & 2432 \\
\hline TOT_A mm² & 759 & 1567 & 1217 & 206 & 830 & 1725 & 1246 & 220 \\
\hline TRAB_A mm² & 341 & 703 & 547 & 93 & 373 & 776 & 560 & 99 \\
\hline CRT_A mm² & 441 & 726 & 603 & 85 & 244 & 707 & 590 & 107 \\
\hline PERI C mm & 98 & 140 & 123 & 11 & 102 & 147 & 125 & 11 \\
\hline ENDO_C mm & 63 & 113 & 87 & 13 & 67 & 120 & 120 & 15 \\
\hline
\end{tabular}

significant differences in the analysed densitometric and geometric parameters between bilateral radius and tibia of horses at both studied levels [24]. Research on the same bones was also carried out at the levels from 15\% to $95 \%$ (every 10\%) of the bone length. They confirmed the earlier observations of no statistically significant differences between the analysed densitometric and geometric parameters for bilateral radius and tibia.

Within the present research, measurements of bilateral proximal phalanges in horses have been taken at three levels: $15 \%, 50 \%$ and $85 \%$ of the bone length. Other researchers have also conducted studies on the both front legs proximal phalanges in horses. However, they compared only densitometric parameters as the analysis was carried out by dual energy $\mathrm{x}$-ray absorptiometry (DXA). When using the above method, the authors of the present paper have not observed any statistically significant differences regarding bone mineral density and bone mineral content between bilateral proximal phalanges [5].
We analysed densitometric as well as geometric parameters for the both front legs proximal phalanges in horses. With the use of $\mathrm{pQCT}$, we demonstrated that all the parameters studied, both densitometric and geometric, measured at $50 \%$ and $85 \%$ of the bone length, did not present any statistically significant differences between the right and left proximal phalanges of the front limb. Thus, the results correspond to the observations regarding other long bones [24,25]. Interestingly, at the same time, our research proved that all the bone parameters mentioned above, measured at $15 \%$ of the bone length, were significantly different for the right and left proximal phalanges. In our research, volumetric bone mineral density at $15 \%$ of the bone length was significantly higher in the right proximal phalanx, whereas geometrical parameters and bone strength (SSI) in this area were significantly higher in left pastern bones. As it turns out, considerably higher increase in geometrical parameters of left pastern bones near the proximal metaphysis, compared to right pastern bones, outweighed the relatively
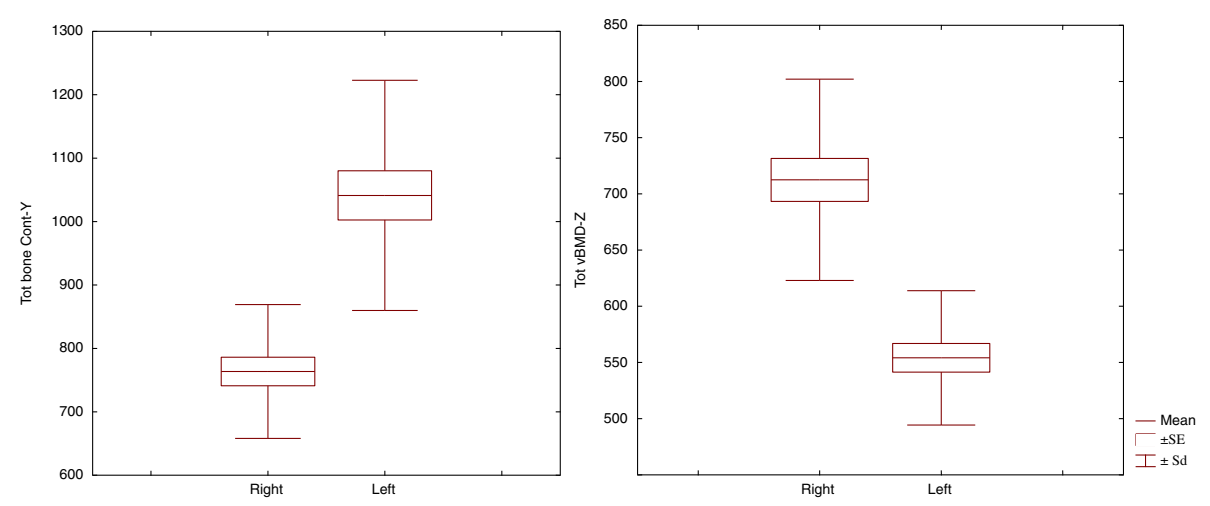

Figure 1 Densitometric parameters for 22 pairs of proximal phalanges analysed in $15 \%$ of the bone length. Left - BMC $\mathrm{mg} / \mathrm{mm}$, right - VBMD $\mathrm{mg} / \mathrm{cm} 3$. 

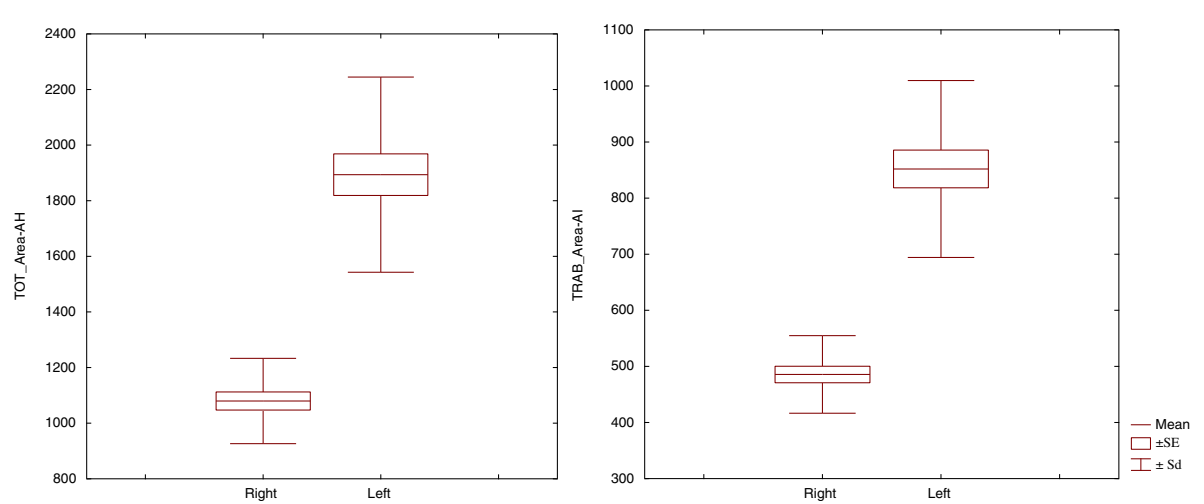

Figure 2 Geometric parameters, describing bone surface in the analysed area for 22 pairs of proximal phalanges analysed in $15 \%$ of the bone length. Left - TOT_A mm², right - TRAB_A mm².

small increase in mineral nutrients. This resulted in lower vBMD in left pastern bones, compared to right pastern bones. Tests conducted on the radius and tibia of horses revealed that the $\mathrm{vBMD}$ value did not increase as a result of physical exercise but bone strength to forces did. Physical exercise, on the other hand, caused an increase of bone mineral content in the radius and tibia [24]. Our research indicated that BMC measured at $15 \%$ of the proximal phalanx length was significantly higher in the left proximal phalanx.

Both parameters describing the analysed bone areas: total bone area and trabecular area, were also significantly higher in left proximal phalanx. Moreover, left side bones at $15 \%$ of the bone length presented higher periosteal circumference and endocortical circumference, parameters whose value grew with the increase in bone strength. Bone section plays an important role in their resistance to bending and twisting. Larger diameter of left pastern bones proves they are more resistant to these forces. The above parameters are, for example, significantly higher in horses that are trained, compared to those that do not undergo training [25].

According to other researchers' observations, forces induced by physical exercise such as cantering and galloping cause an increase in periosteal circumference and endocortical circumference as well as Strength Strain Index in the radius and tibia. On the other hand, there was no increase in cortical thickness in trained horses. Values of this parameter did not present significant differences between the trained and untrained groups of horses [25].

Therefore, it can be assumed that the higher cortical thickness of the right side bones that was observed in our study does not translate into their higher strength.

At the same time, our study showed that another parameter describing the compact bone tissue, cortical area, at $15 \%$ of the bone length was significantly higher in left
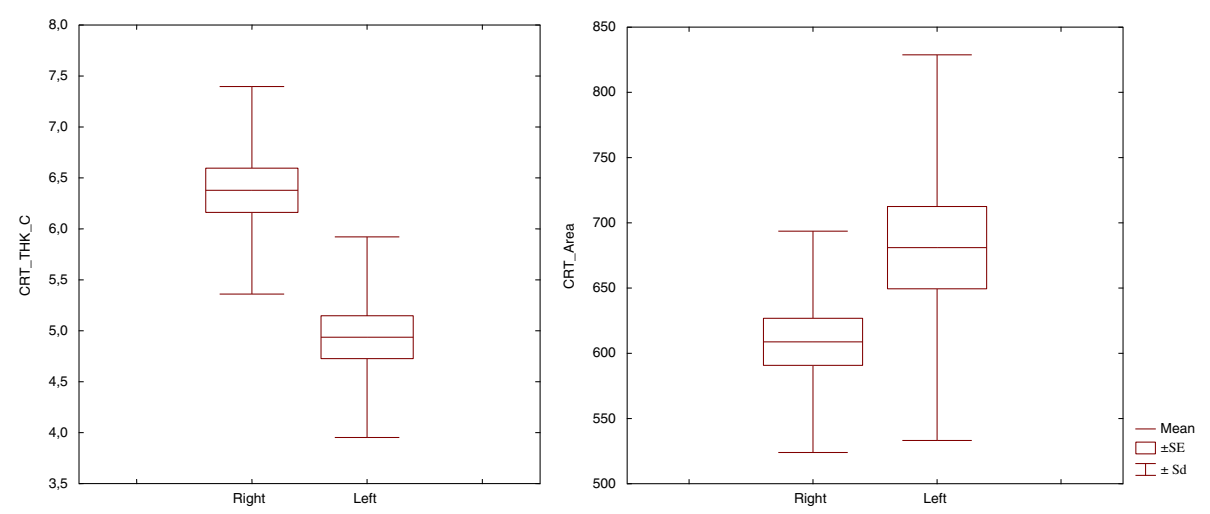

Figure 3 Geometric parameters for the compact bone tissue in the analysed area for 22 pairs of proximal phalanges analysed in $15 \%$ of the bone length. Left - CRT_THK_C mm, right CRT_A mm². 

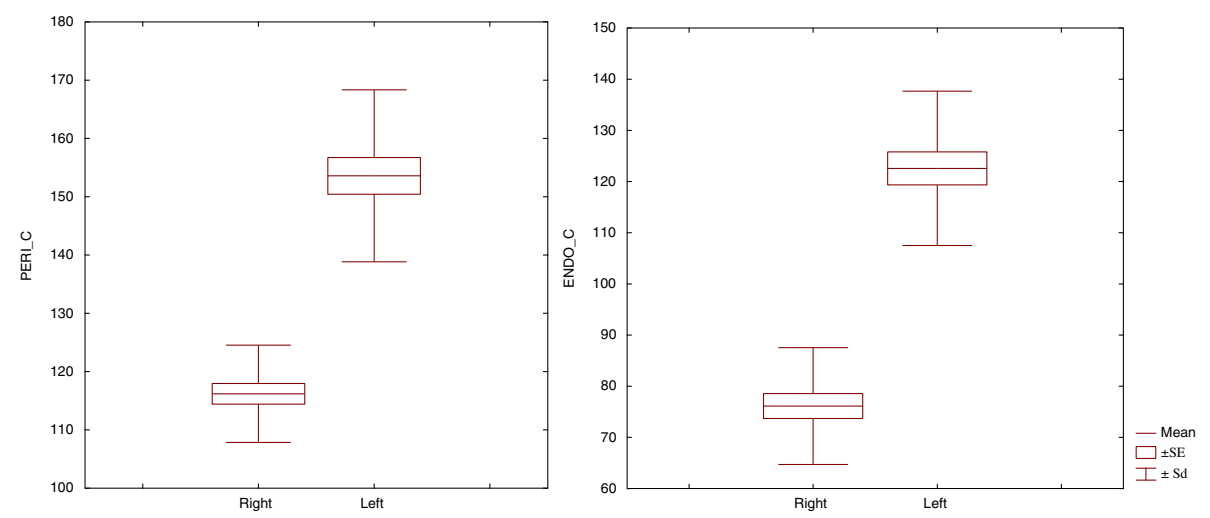

Figure 4 Geometric parameters for the external (subperiosteal) and internal circumferences of the compact bone in the analysed area for 22 pairs of proximal phalanges analysed in $15 \%$ of the bone length. Left PERI C mm, right ENDO C mm CRT_THK_C.

proximal phalanges. Higher strength of left side pastern bones compared to right pastern bones at $15 \%$ of the bone length is also evidenced by the fact that the expected Strength Strain Index in this area was significantly higher in the left proximal phalanx. Combined effect of the increase in such parameters as periosteal circumference, endocortical circumference and cortical area signifies the rise in bone strength $[25,29]$. Our study clearly showed that the parameters in bilateral proximal phalanges differ significantly at $15 \%$ of the bone length. It was also observed that all the parameters that suggest higher strength of bones to such forces as: bone mineral content, total bone area, trabecular area, cortical area, periosteal circumference, endocortical circumference, Strength Strain Index, were significantly higher for left proximal phalanges. Strength Strain Index was even two times higher.

Bones undergo constant remodeling during lifespan. Bone cell activity is determined by general factors such as hormones and vitamins, and local factors, e.g. Insuline -like Growth Factor, interleukins (IL-6, IL-3, IL-1), or TGF $\beta$-Transforming Growth Factor [30]. For the

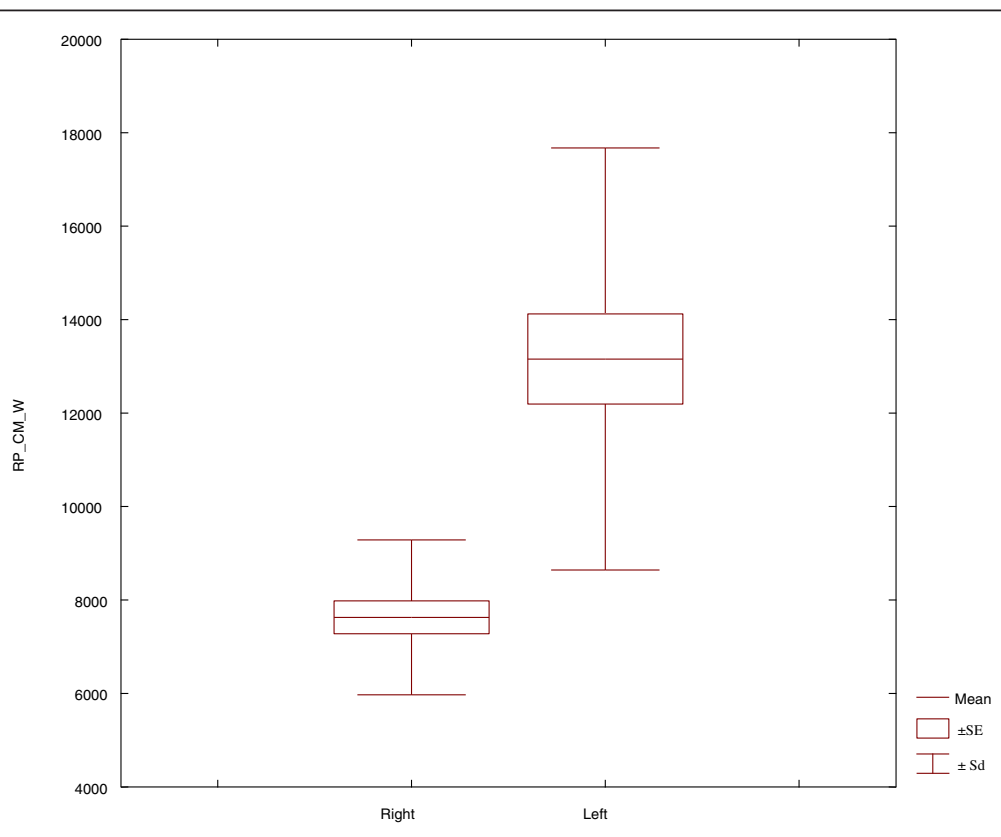

Figure 5 Expected RP_CM_W mm mm $^{3}$ for 22 pairs of proximal phalanges analysed in $15 \%$ of the bone length. RP_CM_W. 
remodeling process to begin, i.e. for the bones to change their structure, initiating factors for osteoblast precursors are necessary [31]. What is also important with regard to remodeling is physical factors, which are particularly significant in determining the microstructure of the bone tissue [32-34]. Due to the fact that our study involved comparing bilateral bones in the same animal, we were able to assess the influence of asymmetrical strain exerted during the animal's movement on the differentiation of geometrical and densitometric parameters at given lengths of the pastern bone. Since the study showed statistically significant differences at $15 \%$ of the bone length, which is quite novel, it is recommended to conduct a similar study in a larger population of horses.

\section{Conclusions}

Our results confirm the observation that every bone reacts individually to load forces, which is related to its location, shape and function. Simultaneously, mechanisms that modulate bone density and microstructure can cause significant changes in the bone at a certain level, leaving the remaining bone length unaffected. Proximal phalanges undergo the most substantial changes in microstructure in the vicinity of proximal metaphysis. Another observation is that, compared to right side proximal phalanges, left side proximal phalanges in forelimbs in the vicinity of the proximal metaphysis are characterised with significantly higher parameters, which manifest higher Strength Strain Index.

In our study, the most distinct differences between the right and left pastern bones were observed at $15 \%$ of the diaphyseal length, i.e. in the areas where the spongious substance is most abundant. According to our hypothesis, this may happen because the metabolism of the spongious bone tissue is eight times faster compared to the compact bone tissue. Bone metabolism is most intensive in the spongious substance due to a larger area for osteoblasts and osteoklasts to operate, larger blood supply and better access to tissue fluids. Thus, the spongious substance displays the highest diagnostic value since any pathological changes as well as changes caused by different strains are the earliest to be observed here. Our observations suggest that this type of research should be continued within a larger population.

\footnotetext{
Abbreviations

PQCT: Peripheral quantitative computed tomography; BMC: Bone mineral content; vBMD: Volumetric bone mineral density; TOT_A: Total bone area; TRAB_A: Trabecular area; CRT_A: Cortical area; CRT_THK_C: The mean cortical thickness; PERI C: Periosteal circumference; ENDO_C: Endocortical circumference; SSI =RP_CM_W: Strength Strain Index; t: t-student test; Z: Wilcoxon paired samples test; SD: Standard deviation; P: Significant statistical differences..
}

\section{Competing interests}

The authors declare that they have no competing interests.

\section{Author details}

'Department of Morphological Science, Faculty of Veterinary Medicine, Warsaw University of Life Sciences, Nowoursynowska 166, Warsaw 02-776, Poland. ${ }^{2}$ Vertebrates Morphology Department, University of Natural Sciences and Humanities, Siedlce 08-110, Poland.

\section{Authors' contributions}

$M D$ - the initiator of the study, who conducted the main experimental part, performed the statistical calculations and described the results. AC - result advisor, who participated in collecting the research material. Both authors read and approved the final manuscript.

Received: 13 January 2012 Accepted: 13 July 2012

Published: 13 July 2012

\section{References}

1. Dzierzęcka M, Wąsowski AJ, Kobryń H: Leg bones injuries during race training in two- year-old thoroughbred horses. Med Wet 2007, 63:574-577.

2. Yovich JV, Mcllwraith CW: Arthroscopic surgery for osteochondral fractures of the proximal phalanx of the metacarpophalangeal and metatarsophalangeal (fetlock) joints in horses. J Am Vet Med Assoc 1986, 188:273-279.

3. Ellis DR, Simpson DJ, Greenwood RE, Crowhurst JS: Observations and management of fractures of the proximal phalanx in young Thoroughbreds. Equine Vet J 1987, 19:43-49.

4. Parkin TD, Clegg PD, French NP, Proudman CJ, Riggs CM, Singer ER, Webbon PM, Morgan KL: Risk of fatal distal limb fractures among Thoroughbreds involved in the five types of racing in the United Kingdom. Vet Rec 2004, 154:493-497.

5. Tóth P, Horváth C, Ferencz V, Nagy K, Gligor N, Szenci O, Bodó G: Assessment of the mineral density and mineral content of the equine third metacarpal and first phalanx bone by dual energy x-ray absorptiometry. Acta Vet Hung 2010, 58:317-329.

6. Firth EC, Rogers CW, van Weeren PR, Barneveld A, Mcllwraith CW, Kawcak CE, Goodship AE, Smith RK: Mild exercise early in life produces changes in bone size and strength but not density in proximal phalangeal, third metacarpal and third carpal bones of foals. Vet J 2011, 190:383-389.

7. Alho A: Mineral and mechanics of bone fragility fractures. Acta Orthop Scan 1993, 64:227-232.

8. Czerwiński E: Radiological and densitometric diagnostics of osteoporosis. Przegl Lek 1997, 4:220-225.

9. Claes LE, Wilke HJ, Kiefer H: Osteonal structure better predicts tensile strength of healin bone than volume fraction. J Biomech 1995, 28:1377-1390.

10. Chappard D, Legrand E, Basle MF, Audran M: Measuring trabecular bone architecture by image analysis of histological sections. Eur Microsc Anal 1997, 11:13-15.

11. Walters J, Koo WW, Bush A, Hammami M: Effect of hand dominance on bone mass measurement in sedentary individuals. J Clin Densitom 1998, 1:359-367.

12. Akar S, Sivrikaya H, Canikli A, Varoğlu E: Lateralized mineral content and density in distal forearm bones in right-handed men and women: relation of structure to function. Int J Neurosci 2002, 112:131-301.

13. Sanchis-Moysi J, Dorado C, Olmedillas H, Serrano-Sanchez JA, Calbet JA: Bone mass in prepubertal tennis players. Int J Sports Med 2010, 31:416-420.

14. Gümüştekin K, Akar S, Dane S, Yildirim M, Seven B, Varoglu E: Handedness and bilateral femoral bone densities in men and women. Int J Neurosci 2004, 114:1533-1547.

15. Llorente M, Riba D, Palou L, Carrasco L, Mosquera M, Colell M, Feliu O: Population-level right-handedness for a coordinated bimanual task in naturalistic housed chimpanzees: replication and extension in 114 animals from Zambia and Spain. Am J Primatol 2011, 73:281-290.

16. Smith HM, Thompson CL: Observations of hand preference in wild groups of white-faced sakis (Pithecia pithecia) in Suriname. Am J Primatol 2011, 73:655-664.

17. Blendinger W: Psychologie und Verhaltenweisen des Pferdes. Peter Thein, München-Wien- Zürich: Recht; 1984.

18. Pearce GP, May-Davis S, Greaves D: Femoral asymmetry in the Thoroughbred racehorse. Aust Vet J 2005, 83:367-370.

19. Davies HM, Watson KM: Third metacarpal bone laterality asymmetry and midshaft dimensions in Thoroughbred racehorses. Aust Vet J 2005, 83:224-226. 
20. Ramzan PHL, Palmer L: Musculoskeletal injuries in Thoroughbred horses: a study of three large training yards in Newmarket UK (2005-2007). Vet J 2011, 187:325-329.

21. Laib A, Häuselmann HJ, Rüegsegger P: In vivo high resolution 3D-QCT of the human forearm. Technol Health Care 1998, 6:329-337.

22. Laib A, Rüegsegger P: Calibration of trabecular bone structure measurements of in vivo three-dimensional peripheral quantitative computed tomography with 28-microm-resolution microcomputed tomography. Bone 1999, 24:35-39.

23. Link TM, Bauer JS: Imaging of trabecular bone structure. Semin Musculoskelet Radiol 2002, 6:253-261.

24. Fürst A, Meier D, Michel S, Schmidlin A, Held L, Laib A: Effect of age on bone mineral density and micro architecture in the radius and tibia of horses: an Xtreme computed tomographic study. BMC Vet Res 2008, 25:1-12.

25. Nicholson CL, Firth EC: Assessment of bone response to conditioning exercise in the radius and tibia of young thoroughbred horses using pQCT. J Musculoskelet Neuronal Interact 2010, 10:199-206.

26. Whitton RC, Trope GD, Ghasem-Zadeh A, Anderson GA, Parkin TD, Mackie EJ, Seeman E: Third metacarpal condylar fatigue fractures in equine athletes occur within previously modelled subchondral bone. Bone 2010, 47:826-831.

27. Claerhoudt $\mathrm{S}$, Bergman EH, van der Veen $\mathrm{H}$, Vanderperren $\mathrm{K}$, Raes EV, Saunders $\mathrm{JH}$ : Computed tomographic morphology of the synovial invaginations of the distal sesamoid bone of the horse. Anat Histol Embryol 2011, 40:55-60.

28. Komosa M, Moliński K, Godynicki S: The variability of cranial morphology in modern horses. Zoolog Sci 2006, 23:289-298.

29. Robling AG, Hinant FM, Burr DB, Turner $\mathrm{CH}$ : Improved bone structure and strength after long-term mechanical loading is greatest if loading is separated into short bouts. J Bone Miner Res 2002, 17:1545-1554.

30. Dziedzic-Gocławska A: Tkanka kostna. Histologia, Wyd. Warszawa: PZWL; 1995. in polish.

31. Piastowska AW: Influence of biologically active substances from soybean on mineral content and mechanical properties of bones in rats. In Doctoral Thesis.: Warsaw University of Life Sciences; 2005.

32. Advani S, Wimalawansa SJ: Bones and nutrition: common sense supplementation for osteoporosis. Corr Womens Health Rep 2003, 3:187-192.

33. Matrin RB, Ishida J: The relative effects of collagen fiber orientation. Porositt, density and mineralization on bone strength. J Biochem 1989, 22:419-426.

34. Turner $\mathrm{CH}$, Robling AG: Designing exercise regiments to increase bone strength. Exerc Sport Sci Rev 2003, 31:45-50.

doi:10.1186/1751-0147-54-41

Cite this article as: Dzierzęcka and Charuta: The analysis of densitometric and geometric parameters of bilateral proximal phalanges in horses with the use of peripheral quantitative computed tompgraphy. Acta Veterinaria Scandinavica 2012 54:41

\section{Submit your next manuscript to BioMed Central and take full advantage of:}

- Convenient online submission

- Thorough peer review

- No space constraints or color figure charges

- Immediate publication on acceptance

- Inclusion in PubMed, CAS, Scopus and Google Scholar

- Research which is freely available for redistribution 